\title{
Policy accommodation versus electoral turnover: policy representation in Britain, 1945-2015
}

\author{
JOHN BARTLE \\ Department of Government, University of Essex, UK \\ E-mail: jbartl@essex.ac.uk
}

SEBASTIAN DELLEPIANE AVELLANEDA

School of Public Policy, University of Strathclyde, UK

E-mail: sebastian.dellepiane@strath.ac.uk

\section{ANTHONY MCGANN}

School of Public Policy, University of Strathclyde, UK E-mail: anthony.mcgann@strath.ac.uk

\begin{abstract}
Does public policy in the United Kingdom respond to changes in public preferences? If so, is this the result of the government changing its policy to reflect preferences ("policy accommodation") or the result of governments that pursue unpopular policies being replaced at elections by governments more in line with the public ("electoral turnover")? We explore these questions by estimating annual aggregate public preferences ("the policy mood") using responses to 287 questions administered 2,087 times and annual policy using budgetary data ("nonmilitary government expenditure") for the whole of the postwar period. We find that mood moves in the opposite direction to policy and variations in mood are associated with variations in annual vote intentions. Policy is responsive to party control but not directly responsive to mood. Shifts in mood eventually lead to a change in government and thus policy, but this process may be very slow if the public has doubts about the competence of the opposition.
\end{abstract}

Key words: accommodation, electoral turnover, policy mood, representation, responsiveness

In this article, we examine whether the policy in Britain is shaped by public preferences. We examine two accounts by which policy responsiveness could be achieved. "Policy accommodation" suggests that office-seeking governments respond directly to changes in preferences by changing policy. "Electoral turnover", on the other hand, suggests that policy responds indirectly. Parties pursue policies consistent with their ideology. The 
public's preferences respond to policy "thermostatically", moving right as policy moves left and left as it moves right (Wlezien 1995). These movements produce changes in vote intentions and, ultimately, a turnover of power from one "side" to the other. This process, however, may only operate after a considerable time lag if the public initially lacks faith in the competence of the opposition.

There are two sets of reasons why we should be concerned with whether the policy is responsive to public opinion. First, from a strictly positive point of view, we want to know to what degree government policy is constrained by public opinion. To what degree are policymakers forced to react to changes in public opinion and to what degree are they able to act independently of it? Second, from a normative point of view, we are interested in how "well" democracy is functioning - do governments act in a way that is representative of the public? Of course, there are many different conceptions of democracy, some of which do not require the congruence of public opinion and policy in a substantive sense. ${ }^{1}$ Nevertheless, the basic meaning of democracy is that the "people rule", and this is often interpreted to mean that the people should have control of the broad direction of policy (May 1978; Rehfeld 2009; Petitt 2010). As Andrew Rehfeld puts it, “... the presumption of democracy is that there be a close correspondence between the laws of a nation and the preferences of citizens who are ruled by them" $(2009,214)$.

However, when we consider representative democracy, it is not immediately obvious how responsive policy should be to public opinion, especially if we embrace a trustee conception of representation. If we think that the appropriate form of representation is a delegate model - the government ought to follow the instructions of the people - and we apply this to the government as a whole as opposed to individual representatives, then we should expect government policy to follow public opinion. ${ }^{2}$ Of course, it is still necessary to interpret what the people's "instructions" are. $^{3}$

${ }^{1}$ For example, there are "minimalist" theories of democracy, which argue that the value of democracy is simply the discipline imposed on governments by the fact they can be replaced (Schumpeter 1942; Weber 1978; Riker 1982). Przeworski (1999) goes as far as to argue that even the random replacement of governments could bring many of the benefits of democracy. Other theories of democracy are strictly procedural, arguing that democracy should be defined in terms of the fairness of the institutions, rather than its policy outcomes. The "populist theory of democracy" in Dahl's (1956, Chapter 2) Preface to Democratic Theory is of this kind.

${ }^{2}$ If representatives act as delegates for separate constituencies, we may not observe responsiveness to public opinion as a whole. For example, delegates who are strictly bound by the instructions of their constituents may lack the discretion necessary to reach the compromises needed to pass any legislation at all.

${ }^{3}$ Of course, the public does not in general issue explicit instructions. Rather, we need to infer the intentions of the public from election results. For example, parties may offer electoral 
Even in this case, we might expect the government to follow the will of the people in broad terms rather than in terms of specific policies. Following Christiano (1996, 215-217), we might expect the government to be a delegate in terms of ends, while being a trustee in terms of means.

However, if we endorse a trustee model of representation - representatives are expected to use their judgement to advance the interests of the people to the best of their ability - then a considerable amount of slippage between public opinion and policy may be completely acceptable in a democracy. It is still possible that trusteeship will produce a high degree of responsiveness. If the people choose trustees whose values and interests align closely with their own, they may choose policies that naturally track the preferences of the public (what Mansbridge 2003 terms "gyroscopic representation"). Similarly, trustee representation and popular control could be reconciled through deliberation and public reason, in what Pettit calls "interpretive representation". ${ }^{4}$ On the other hand, while trustees are expected to act in the interest of the public, they also may choose policies that differ from what the public wants. If the policies demanded by the public want are impossible or ill-advised (they do not achieve the ends the public wishes to achieve), then trustee representation will result in policies that diverge from what the public wants. ${ }^{5}$

However, it is important not to take this argument too far. While trustee representation allows for some slippage between public opinion and policy, we should still be concerned if there is a complete disconnect. If democratic trusteeship allows the public to be completely disregarded, then there is a danger that it simply becomes a euphemism for benign despotism or paternalism. A trustee, according to Burke (2009), must make decisions in the interests of the people, and may not substitute their own interests in place of those of the people. When we observe government policy diverging from public opinion, we are faced with the question as to whether this is the legitimate use of trusteeship in the interests of the people, or whether the government is substituting its own interests for those of the people. Lack of

programmes and pledges, and the public may endorse them by electing the party (what Mansbridge 2003 refers to as "promissory representation"). Alternatively, governments could observe public opinion and react to what the public wants, anticipating that the electorate will punish it at the next election if it does not ("anticipatory representation" in Mansbridge's terminology).

${ }^{4}$ Petitt (2010) rejects the idea that public opinion exists exogenously and controls policy, and argues that a trustee conception of representation is inevitable. However, he argues that public opinion and policy correspond to one another in a democracy because both are determined by the same process of deliberation and public reason. Indeed Petitt $(2010,82)$ argues that the Westminster system is responsive to public opinion precisely because the representatives behave as trustees.

${ }^{5}$ We might also consider the standard proposed by Fishkin (1995), who argued that representatives should adopt the policies the public would choose if they were properly informed. 
policy responsiveness certainly does not prove that there has been a failure of democratic representation, but it does call for explanation and justification. As Rehfeld argues, "we must always justify and explain cases in which law deviates from citizen preferences, whereas no such prima facie justification is required in cases when law conforms to the preferences and wills of those it governs" $(2009,214)$.

Thus, while responsiveness does not give us a simple measure of democratic representation, it can still provide a valuable test of it. We would argue that the responsiveness of aggregate public spending to public opinion is actually a more appropriate test than the responsiveness of particular policies or the budget allocations to particular departments. This is because it is a very general measure of policy that reflects broad visions of society, rather than specific policy expertise. If detailed public policies do not reflect public opinion, a government can always claim that it is acting as a trustee, using its superior technical knowledge to make informed decisions. It may even claim that what the public wants is impossible. However, it is clearly possible to have different levels of aggregate spending and taxes, as this varies greatly amongst countries. ${ }^{6}$ Furthermore, there does not exist a technocratic consensus about what the appropriate size of government is; rather this appears to be a matter of values, and the type of society people prefer. If the government persistently ignores public opinion in such a general sense, we may well worry that it has exceeded its role as trustee and substituted its own values for those of the people.

In addition to the policy responsiveness we study, other forms of responsiveness may also be valuable in testing how representative government is. One example is attention responsiveness (Jennings and John 2009; Bertelli and John 2013; John et al. 2013; Bevan and Jennings 2014). This considers the degree to which the policy priorities of governments (typically measured by the weight given to various policy areas in the Queen's speech) corresponds to the policy priorities of the public (usually measured by the answer to the question of what is the most important problem facing the country). While policy responsiveness and attention responsiveness both deal with the allocation of a scare resource (money or time), they seem to behave quite differently (see Bevan and Jennings 2014; Jennings and Wlezien 2015). ${ }^{7}$ Nevertheless, if a government is representative of the people, we

${ }^{6}$ In 2015 government spending as percentage of GDP in Organisation for Economic Cooperation and Development (2017) countries varied from 29\% in Ireland to 57\% in Finland.

${ }^{7}$ Bevan and Jennings (2014) find that while government attention (measured by either mentions in the Queens speech or legislation) does respond to the public's assessment of problems, government spending does not in a statistically significant way. Jennings and Wlezien 
would expect it to pay attention to the issues that the people think are important, even if it does not necessarily allocate more money to these areas. If a government consistently ignores the issues the people think are important, we are surely entitled to ask whether the government is really representing the interests of the people.

While responsiveness may not provide us with a direct measure of democratic representation, it does provide a valuable of a test of it. If we do not observe responsiveness (whether in policy or attention), this may serve as a warning flag that demands explanation. This caveat aide, we examine the relationship between preferences and policy in Britain from 1945 to 2015 using macrolevel indicators and appropriate time series methods. In the next section, we introduce the left-right framework to summarise preferences and policy. In the next two sections, we conceptualise both these as time series ("the policy mood" and "nonmilitary government spending") that respond to each other. We describe the time series models in some detail before examining the two steps in the "electoral turnover" mechanism (whether mood responds to policy and vote to mood). We then examine both the final stage in the electoral turnover mechanism (whether policy responds to the party) and the policy accommodation mechanism (whether policy responds to mood). We finally compare our findings with previous studies and then we draw conclusions about the impact of party ideology.

\section{The left-right framework}

Disagreements about goals are central to most accounts of representative democracy because they motivate parties and electorate alike (Downs 1957). Parties pursue ideological goals subject to electoral considerations (Strøm 1990). The electorate wants governments both to produce policy that honours their values and govern with competence (Stimson et al. 1995; Erikson et al. 2002). Preferences and positions link parties with the electorate and provide the basis for effective communication (Scarbrough 1984).

There are a very large number of issues that people disagree about. If we are to understand the interaction between parties and the electorate we need to cut away inessential detail (Budge 2006). Accordingly, we assume that the interaction between parties and the electorate takes place along a single left-right dimension (Downs 1957). The preferences that are of interest to us are those on which the parties have taken positions. "Left" means those

(2015) show that the public perception of a problem being important does not in general correlate with a public demand for more money to be spent on the issue. 
preferences expressed or positions adopted by Labour. "Right" means those adopted by the Conservatives (Budge and Farlie 1977).

Parties aim to attract voters. They take positions on a wide range of issues. Some are enduring. Some are transient. The "core" issues that divide the major parties relate to economics. Labour has generally supported "more" government activity, "more" collective action and "more" equality. The Conservatives have generally supported "less" (Blais et al. 1993). Nevertheless, Labour and the Conservatives disagree on other issues relating to law and order, individual freedom, the environment and international affairs. As new issues emerged, the parties have adopted opposing positions, and these have acquired "left" or "right" polarities (Carmines and Stimson 1989). It is usual, for example, to label support for shorter sentences, equal rights for gays, environment protection and international cooperation as "left-wing". This enables analysts to use texts to summarise party positions using both economic and noneconomic positions. The MARPOR "RILE" scores, for example, provide evidence about how parties compete for office (Budge et al. 2001; McDonald and Budge 2005).

There are doubts whether public preferences can be so simplified (Budge 2006). Fortunately, it is not necessary to resolve the vexing issue of the "real" structure of public preferences here (Stimson 2004). Our purpose is simply to summarise preferences in such a way as to understand the interaction between parties and the electorate. Accordingly, we focus on the core economic issues that represent the enduring differences between the parties relating to government intervention, collective action and economic equality (Heath et al. 1994). This decision also simplifies the measurement of policy since it is difficult - if not impossible - to produce annual measures of policy that incorporate both economic and noneconomic issues using textual data. ${ }^{8}$

\section{Measuring macrolevel preferences: annual policy mood}

If we are to analyse responsiveness we need a public preference time series (Erikson et al. 2002). Microlevel theories provide us with good reasons for believing that we can use preferences across a wide range of issues to produce an annual indicator of public preferences. Many issues become "seemingly relate" and acquire "left-right" polarities (Carmines and Stimson 1989). Since most people have low levels of political awareness, they absorb both "left" and "right" considerations (Zaller and Feldman

\footnotetext{
${ }^{8}$ See Hakhverdian (2010) for such an attempt.
} 
1992). The typical individual is "ambivalent" about issues. Their responses to questions depend on their predispositions, the issues raised, precise wording and response options offered. Individual predispositions can be viewed as a running tally of "left" and "right" considerations across all issues. If we could aggregate preferences across both individuals and issues, this "double summation" would provide an indicator of the electorate's aggregate (varying) left-right preferences or "policy mood" (Stimson 1999).

We cannot directly average aggregate responses across survey items. Each survey question has its own biases as a result of the issues that it engages, precise wording and response options provided (Zaller and Feldman 1992). Each question has its own metric. Nevertheless, we can use a method - the dyads ratio algorithm - to find a common metric and then aggregate across issues (Stimson 1999). Before we outline this method, however, we describe the data at our disposal.

\section{Data: the preferences database}

Responses to a wide range of survey probes reflect left-right preferences. Variations in responses over time should, therefore, reflect the changing "policy mood" (Stimson 1999). The raw data to estimate mood are aggregate responses to controversial questions. They require people to choose between options, express "preferences", adopt "positions" or take "sides" (Stokes 1963; Ellis and Stimson 2012).

Since mood is inferred by observing changes between two time points, identical questions must be asked in at least two separate years to form "dyads" (Stimson 1999). Items that refer to particular parties or politicians are excluded from the database, since it is difficult to disentangle attitudes to these objects from preferences. ${ }^{9}$ All the data are taken from nationally representative surveys. In total, the database contains 791 items and 5,363 separate readings of preferences. ${ }^{10}$

\section{Content}

Our database consists of responses to many controversial issues on which the parties can be expected to take contrasting positions. Some 287 questions in 2,087 separate readings of preferences $(39.7 \%$ of the total)

${ }^{9}$ Questions that refer to "the government" are a special case. Where the question refers to government in the abstract it is retained. Where it refers to the incumbents, it is not included.

${ }^{10}$ We cannot be claim that we found all the data. We can claim that we used all the data that we could find. The series vary greatly in length. The longest Gallup series on whether "trades unions are a good thing" spans some 45 years and is entered in the database some 58 times. Many others span just two years. The longest series relate to the core issues. 
Table 1. Items topics for policy mood, 1945-2015

\begin{tabular}{|c|c|c|}
\hline Topic or Domain & Number & $\%$ \\
\hline \multicolumn{3}{|l|}{ Economics } \\
\hline Government intervention versus free-market* & 246 & 4.6 \\
\hline Trade unions and industrial relations* & 507 & 9.5 \\
\hline Welfare state and social benefits* & 282 & 5.3 \\
\hline Public versus private ownership* & 215 & 4.0 \\
\hline Public services spending* & 231 & 4.3 \\
\hline Tax and spending* & 159 & 3.0 \\
\hline Poverty, inequality and redistribution* & 314 & 5.9 \\
\hline Inflation and unemployment* & 133 & 2.5 \\
\hline Total economics & 2,087 & 39.3 \\
\hline \multicolumn{3}{|l|}{ Social } \\
\hline Crime and law and order & 317 & 6.0 \\
\hline Moral and social attitudes & 469 & 8.8 \\
\hline Individual rights & 21 & 0.4 \\
\hline Family & 122 & 2.3 \\
\hline Postmaterialist values & 39 & 0.7 \\
\hline Abortion & 134 & 2.5 \\
\hline Total social & 1,102 & 20.7 \\
\hline \multicolumn{3}{|l|}{ Other } \\
\hline Race relations and immigration & 213 & 4.0 \\
\hline Environment & 305 & 5.7 \\
\hline International affairs & 178 & 3.3 \\
\hline Defence spending & 51 & 1.0 \\
\hline Nuclear weapons & 81 & 1.5 \\
\hline Northern Ireland & 53 & 1.0 \\
\hline Europe & 878 & 16.5 \\
\hline British nationalism & 53 & 1.0 \\
\hline Government & 13 & 0.2 \\
\hline Monarchy & 107 & 2.0 \\
\hline Constitutional reform & 78 & 1.5 \\
\hline Religion & 17 & 0.3 \\
\hline Left-right self-placement & 101 & 1.9 \\
\hline Total other & 2,128 & 40.0 \\
\hline Total & 5,317 & 100 \\
\hline
\end{tabular}

Note: *Indicates used to estimate the policy mood.

relate to "core economic" domain, including government intervention, trade unions, public ownership, public spending, taxation, inequality and the trade-off between inflation and unemployment (see Table 1). Another 1,102 readings $(21 \%$ of the total readings) relate to "social" issues. This domain includes crime and law and order, moral and social attitudes, individual rights, the family and abortion. The "other" category (around 
$40 \%$ of all readings) relate to diverse issues including immigration, international affairs, defence spending, nuclear weapons, Northern Ireland, Europe, national sentiment, the monarchy and left-right self-placement.

If we were confident that public preferences - like party positions - were undimensional, we could estimate mood using all the available data. Since we are ignorant of the real structure, we estimate mood using only items relating to the "core economic" issues. Even after this self-imposed restriction, however, there here is more than sufficient data to reliably estimate annual mood.

\section{Coding responses}

Our focus here is on the "core" left-right issues. Responses are scored from high (most left or Labour) and to low (most right or Conservative) responses. It is straightforward to code these items since the parties have taken consistent (opposing) positions. ${ }^{11}$ Assigning the "wrong" polarities to responses makes no difference to the estimates of mood - it simply results in negative factor loadings that alert us to a coding error (Stimson 1999).

All preferences are expressed as an index of preferences:

$$
\text { Index of preferences }=\frac{\sum_{i=1}^{N} \text { Left preferences }}{\sum_{i=1}^{N} \text { Left }+ \text { Right preferences }} \times 100
$$

These indexes reflect then the balance of left-right preferences on controversial issues. They are fed into the dyads ratio algorithm in order to estimate mood.

\section{Method: the dyads ratio algorithm}

The raw index of preferences represents the percentage of all substantive responses that are "left". ${ }^{12}$ Each index is then expressed as a ratio at two time points (years).

$$
R_{i j}=\frac{x_{t+i}}{x_{t+j}}
$$

These dyads have an expected value of 1.0 and can be averaged to produce a rough estimate of underlying preferences $\left(P_{t}\right)$. The algorithm

\footnotetext{
${ }^{11}$ It is not difficult to code responses items as left and right. The exceptions relate to technological issues such as those relating to genetics on which the parties have not taken positions.

12 The mood can also be estimated by McGann's (2014) estimated based on item-response theory. The two methods produce very similar results.
} 
calculates all the possible dyads for each series $x_{t k}$ iteratively and averages them: ${ }^{13}$

$$
P_{t}=\frac{\sum_{k=1}^{N} x_{t k}}{N_{\text {d }}}
$$

Since not all items are equally valid indicators of underlying preferences, each series is weighted by their estimated validity $h i^{2}$.

$$
P_{t}=\frac{\sum_{k=1}^{N} h_{i}^{2} x_{t k}}{h^{2} N}
$$

Using ratios causes the original metric to be lost. This is reintroduced by a standardisation of the latent scale in terms of the validity-weighted means and standard deviations of the input items (Stimson 1999). The individual items are scored as per cent left over per cent left plus per cent right. The estimated mood, therefore, has the same interpretation; 50 is the neutral point. Values above 50 indicate net left preferences and those below 50 indicate net right preferences.

\section{Estimates of the policy mood}

Figure 1 displays the estimated mood from 1945 to 2015 . About $46 \%$ of all variance in observed preferences is common to this mood. The remaining variance - some $54 \%$ - is either specific to the particular issue domain or is item-specific; that is, a function of the specific wording and measurement error for each question (Erikson et al. 2002, 203).

Averaging over many items reduces the noise induced by sampling errors (Stimson 1999). ${ }^{14}$ In the early period from 1945 to 1964, when data are in shorter supply, the series zig-zags (shown by the broken line in Figure 1). In the later period, after 1964, the series is smoother (shown by the unbroken line). Nevertheless, the overall pattern is clear. The series starts off high (left) in the 1950s and then generally drifts down (right) until 1979. ${ }^{15}$ From 1979 onwards the series tracks back up and to the left, peaking in the early 1990s. This pattern matches standard accounts of public opinion (Kavanagh 1988). From 1997 the series drifts down (right) under New Labour. It reaches its lowest point in 2010 when the Conservatives return to power in a coalition government. It then reverses itself under the coalition

\footnotetext{
13 The algorithm estimates dyads both forwards and backwards and averages the two.

${ }^{14}$ The policy mood series can be smoothed using an exponential operator. All the models here use unsmoothed mood.

15 The series bounces up in the late 1940s - probably a result of the thinness of the data. This has no consequences for our analyses. The mood models are estimated from 1948; the vote intentions models from 1951. Bi-annual estimates of the mood produce essentially identical results.
} 


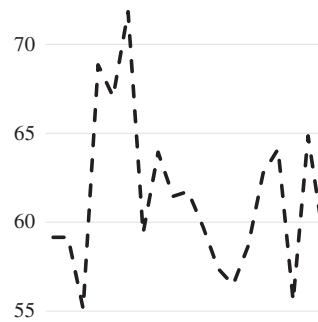

50

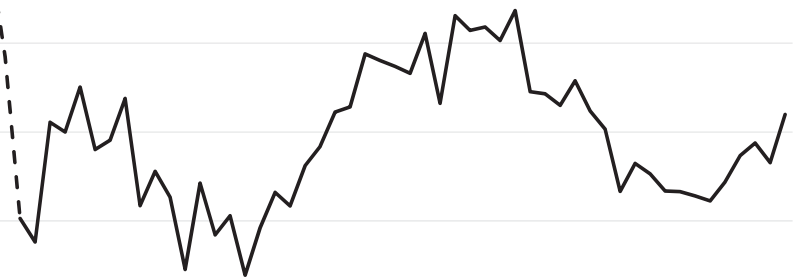

45

40

Figure 1 The policy mood, 1945-2015.

government between 2010 and 2015. Indeed, by 2015, the mood was as far left as it had been in 2004, the year before Labour won a third election victory.

Broadly speaking, these movements seem to be related to the electoral performance of the parties. This suggests that the mood series has a degree of face validity. In particular, three "turning point" elections were presaged by movements in the mood. The Conservative victory in 1979, New Labour's landslide in 1997 and the Tories return to power - as the dominant party in the coalition in 2010 - all appear to reflect prior movements. Yet some election outcomes do not seem to be explicable given movements in the mood. The October 1974 and 1979 general elections, for example, produced a Labour victory on the one hand and a Conservative victory on the other, despite the similar levels of mood. Similarly, the 1992 and 1997 elections produced a Conservative victory and a Labour landslide, though the mood was at much the same level. Other factors - social change, party positions and assessments of party competence - must be taken into account.

In order to illustrate the content of mood, we briefly examine the factor loadings for individual items on the estimated mood series. Since there are 287 series, it is not possible to examine all the loadings. And, since the series vary in length, it would be misleading examine the loadings for all the individual series. Table 2 displays the loadings for the items that are entered into the database in at least 10 years and load at 0.5 or above.

The items that load on mood relate to trade unions, welfare, tax and spending, and inequality. This is a consequence of our decision to include only 
Table 2. Item loadings of policy mood, 1945-2015

\begin{tabular}{llll}
\hline \hline Abbreviated question & House & $N$ & Loading \\
\hline Trade unions are a good thing & Gallup & 40 & 0.96 \\
Welfare makes people less able to stand on feet & BSA & 25 & 0.94 \\
Increase taxes and spending & Gallup & 19 & 0.92 \\
Trade unions too powerful & Gallup & 24 & 0.91 \\
People on benefits do not deserve them & BSA & 25 & 0.90 \\
Spend more on welfare & BSA & 25 & 0.88 \\
Class struggle & BSA & 14 & 0.87 \\
Trade unions too powerful & Mori & 18 & 0.83 \\
Benefits are too high or low & BSA & 30 & 0.83 \\
Increase tax and spending & BSA & 31 & 0.82 \\
Unemployed could find a job if wanted & BSA & 25 & 0.81 \\
Cutting benefits damages lives & BSA & 15 & 0.81 \\
Gap between incomes too large & BSA & 26 & 0.74 \\
Government should redistribute income & BSA & 29 & 0.73 \\
Government spend more on pensions & Gallup & 20 & 0.72 \\
Trade unions extreme & Mori & 15 & 0.71 \\
People fiddle on dole & BSA & 25 & 0.68 \\
Trade unions are essential & Mori & 18 & 0.68 \\
Welfare state proud achievement & BSA & 16 & 0.67 \\
Compulsory trade union membership & Gallup & 11 & 0.66 \\
Social class affects opportunities & BSA & 10 & 0.65 \\
One law for the rich and one law for poor & BSA & 28 & 0.65 \\
Business too powerful & BSA & 11 & 0.57 \\
Welfare state stops self-help & BSA & 14 & 0.55 \\
\hline \hline
\end{tabular}

the "core" issues. The same items would feature prominently in the equivalent table if we had estimated the mood using all the preferences data. ${ }^{16}$ The mood estimated from this larger database, moreover, correlates highly with our mood measure (Pearson's $R=0.90$ ). These observations do not resolve the issue of the dimensionality of preferences. They do reassure us that our decision to use only "core" items is not consequential. Averaging a large number of items produces a robust estimator of preferences.

\section{Measuring annual macrolevel policy}

In order to assess the interaction between governments and the electorate, it is necessary to develop a measure of government policy analogous to our measure of mood. "Policy" is a course of action or the principles adopted

${ }^{16}$ The additional items that would meet joint requirements would include items relating to the European Union, left-right self-placement, environmentalism and postmaterialism. 
by the government. It is difficult to summarise because governments take lots of action make many statements of principle. They legislate, enter into treaties, make administrative decisions, tax and spend, and issue statements of intent. It is also difficult to summarise because it can be indicated by both words (intentions) and deeds (actions and policy delivery).

\section{Nonmilitary government spending}

Spending is a particularly appropriate indicator of delivered policy. It provides a numeraire that gets to the heart of the choice between "more" or "less" (Blais et al. 1996, 43; Soroka et al. 2006). The key indicator of total managed expenditure (TME), for example, summarises government activity in an annual time series. This includes Departmental Expenditure Limits that have been allocated to Departments and Annually Managed Expenditure that is not controlled by government departments. ${ }^{17}$

The parties' preferences about spending reflect their ideologies. Labour governments prefer "more" spending on welfare, health and transport. Conservative governments prefer "less". In some domains, however, these preferences are reversed. The most significant case is defence spending. This fluctuated between a high of $9.8 \%$ of gross domestic product (GDP) in 1953 to a low of $2 \%$ in $2015 .{ }^{18}$ In general, Conservatives prefer more and Labour prefers less spending on defence. Military spending, moreover, is influenced by perceptions of threat and is less responsive to domestic politics. In order to provide a more accurate indicator of domestic policy, we subtract defence as a percentage of GDP spending from TME to produce nonmilitary government expenditure (NMGE).

Figure 2 displays the NMGE series from 1950 through to $2015 .^{19}$ This provides evidence of year on year variation but says little about the impact of party control of government over policy. Figure 3 displays changes in NMGE under governments from 1951 to 2015. Dark blocs indicate Conservative governments; lighter blocs indicate Labour. This tells a fascinating story. All Conservative governments, with the single exception of Heath (1970-1974), have reduced NMGE. ${ }^{20}$ All Labour governments have

\footnotetext{
17 See the Glossary in the Public Finances Data Bank: http://budgetresponsibility.org.uk/docs/ dlm_uploads/PSF_aggregates_databank_September_2016.xls

${ }^{18}$ Data from Stockholm International Peace Research Institute (SIPRI): https://www.sipri. org/databases/milex

19 The NMGE series starts in 1951 because the SIPRI database starts then. This is also convenient since it misses out the major period of demilitarisation 1945-1950.

${ }^{20}$ The Heath government started off by cutting spending but was forced to increase as a result of domestic opposition and the oil-price shocks. Since there was a change of government following the February 1974 election, the end point for the Heath government and the start date for the Wilson government is 1973.
} 


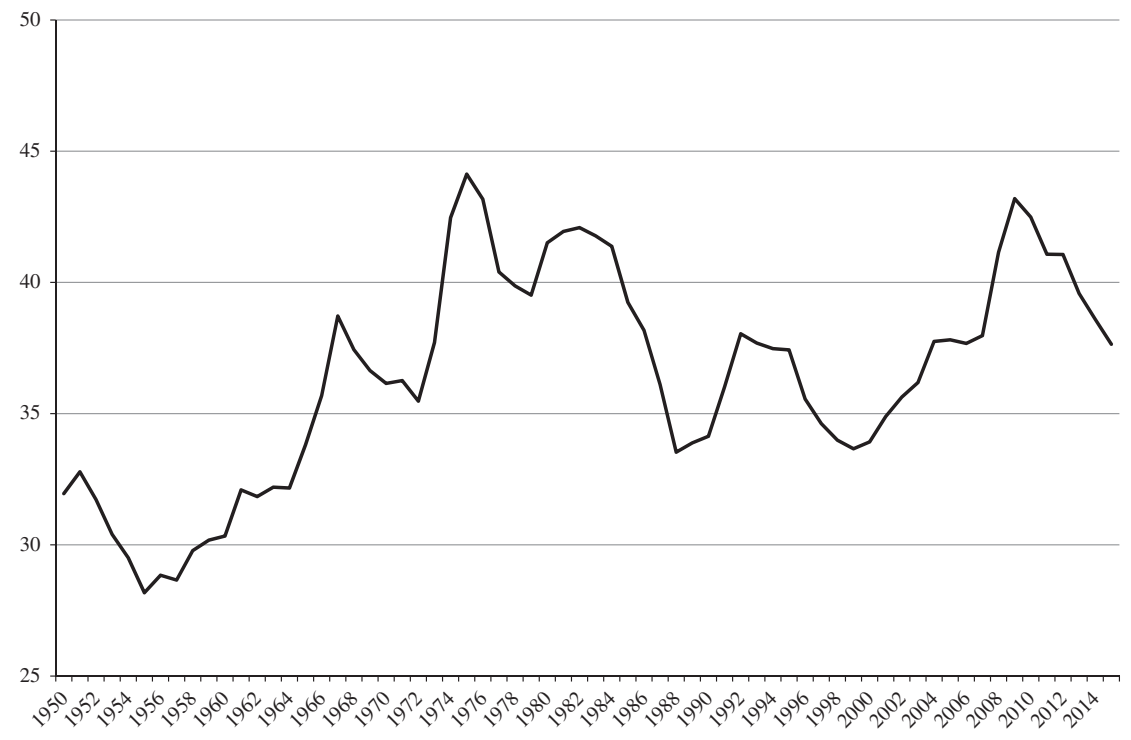

Figure 2 Nonmilitary government spending, 1948-2013.

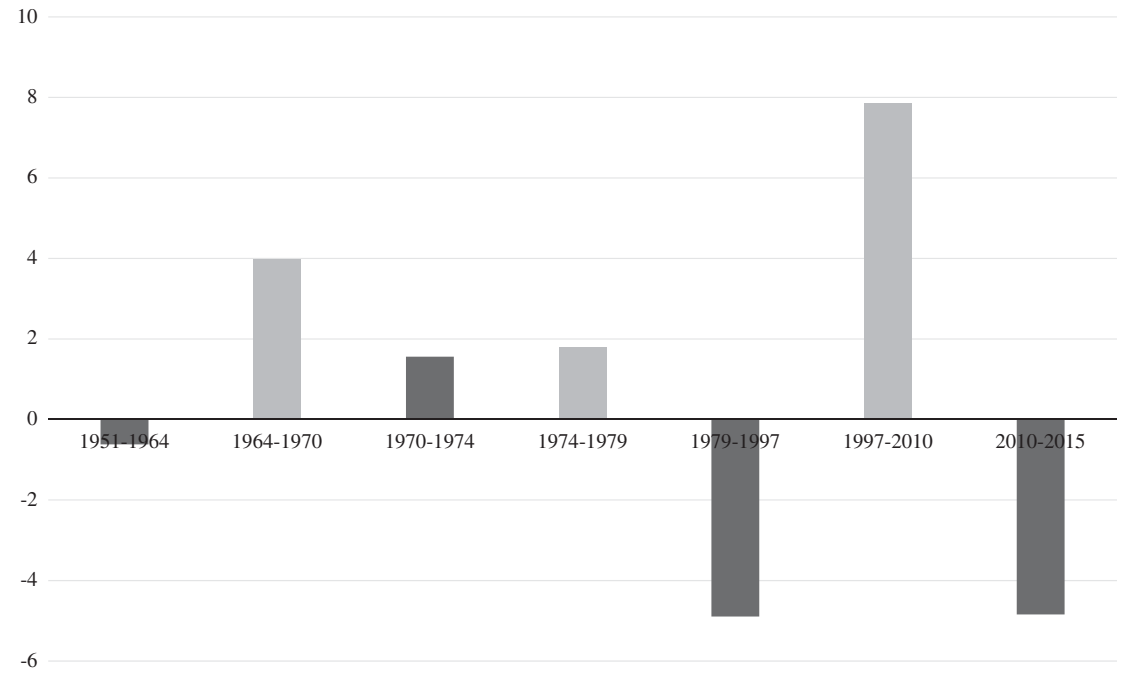

Figure 3 Changes in nonmilitary government expenditure by government, 1951-2015. 


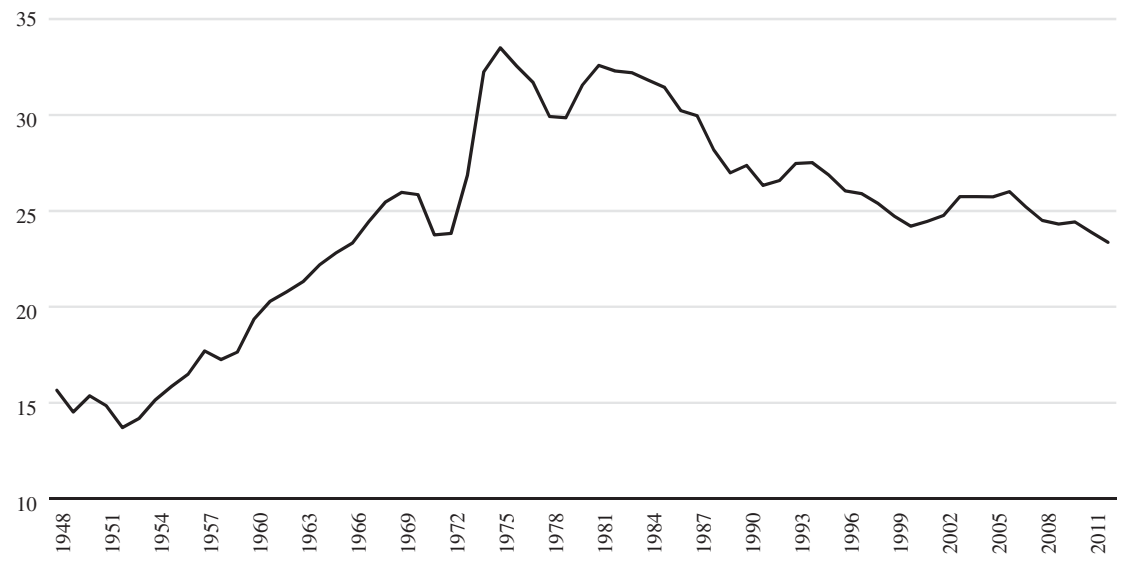

Figure 4 Average direct tax levels (1949-2012).

increased it. Our characterisation of elections as a choice between "more" with Labour and "less" with the Conservatives has a degree of face validity.

\section{Average direct taxation}

The electorate is collectively ambivalent about the government policy activity. They prefer "more" public services. They also prefer "less" bureaucracy and taxation. They also worry about the impact of welfare on individual incentives (Zaller and Feldman 1992). Since it is difficult to produce time series indicators of bureaucracy and incentives, we focus on taxation. ${ }^{21}$ Specifically, we incorporate a measure of the average direct tax (income tax plus national insurance) paid by male workers on median incomes (see Figure 4). ${ }^{22}$ This measure does not, of course, cover all taxes but reflects public debates in Britain, which have centred on direct taxation. ${ }^{23}$

\section{Methodology}

When we inspect the graphs for mood, vote intentions and domestic spending, it is clear that these variables are not stationary. That is to say, they do

${ }^{21}$ In principle, we could incorporate Office for National Statistics indicator of public sector current receipts. This indicator is highly correlated, however, with TME.

22 Direct taxes include income tax and national insurance. Estimates to 2005 were produced by Frances Lynch at the University of Westminster (Johnson et al. 2005). This has been updated to 2013 by the authors.

23 This is despite the fact that income tax generates only $£ 182$ billion of the $£ 721$ billion (25\%) of total revenue in 2016/2017. See H. M. Treasury, Budget 2016 (https://www.gov.uk/ government/uploads/system/uploads/attachment_data/file/508193/HMT_Budget_2016_Web_ Accessible.pdf). 
not oscillate around a single mean, but instead the mean moves over time. Formal stationarity tests confirm this. ${ }^{24}$ Nonstationarity creates problems when analysing time series, in particular the problem of spurious regression (Enders 2004). It is quite likely that two nonstationary variables will correlate significantly, even if they are completely unrelated. We need to ensure that our results are not simply the result of such spurious correlation.

One approach to the problem of nonstationarity is to take the first difference of the data (or further differences if necessary), so we have a stationary time series. This deals with nonstationarity but only allows us to draw inferences about the short-term dynamics of the relationship between the variables. An alternative approach is to use the error correction model approach of the type:

$$
\Delta \mathrm{Y}_{\mathrm{t}}=\mathrm{b}_{0}+\mathrm{b}_{1} \Delta \mathrm{X}_{\mathrm{t}}+\mathrm{a}\left(\mathrm{Y}_{\mathrm{t}-1}-\mathrm{g}_{0}-\mathrm{g}_{1} \mathrm{X}_{\mathrm{t}-1}\right)
$$

This also allows us to model the long-term relationships between the variables. It assumes that there is a long-term equilibrium relationship between the variables, and that the further out of equilibrium we are the larger the adjustment (the parameter a represents the speed of this adjustment). However, error correction models are only appropriate with nonstationary data if the variables are cointegrated (Engle and Granger 1987). Roughly speaking, this means that the variables move up and down in parallel, and the relationship remains approximately the same over the whole time period. ${ }^{25}$ If the variables are not cointegrated, we again face the problem of spurious regression.

We use the error correction model whenever there is a suitable cointegrating relationship. We test for cointegration in two ways. First, we run an augmented Dickey-Fuller test on the residuals of the regression of the variables in levels. Second, the error correction parameter is itself a test of cointegration. However, when using this as a test for cointegration, it is necessary to use the distribution derived by MacKinnon (1994) and Ericsson and MacKinnon (2002), instead of the normal $t$-distribution reported by most software packages (see Grant and Lebo 2016). We find strong evidence of cointegration in our models with mood and vote intentions as the dependent variable, and use error correction models in these cases. However, we do not find sufficient evidence of cointegration for our model explaining NMGE. In this case, we take the first difference of government spending, modelling the change in government spending as a

\footnotetext{
${ }^{24}$ The augmented Dickey-Fuller statistics (lag order 3 ) for the three dependent variables were as follows: Policy mood $-2.02(\mathrm{p}=0.57)$; Vote intentions $-2.43(\mathrm{p}=0.40)$; Domestic spending $-1.93(\mathrm{p}=0.60)$. In all cases the null hypothesis of a nonstationary unit root process cannot be rejected.

${ }^{25}$ Formally this requires that when the variables are regressed, the error term is stationary.
} 
function of mood and economic conditions. This is similar to the approach in Soroka and Wlezien (2009).

There has recently been a debate about the appropriateness of error correction models in political science. In a special edition of Political Analysis, Grant and Lebo (2016) argue that many applications of error correction models are inappropriate because they are applied to data where cointegration is not present. They suggest that the conditions required to use error correction models rarely apply in political science. Others have argued that error correction models are more widely applicable (Enns et al. 2016; Esarey 2016; Keele et al. 2016). ${ }^{26}$ However, there is agreement that if the data are nonstationary, error correction models are only appropriate where cointegration is present. We only use error correction models where there is clear evidence of cointegration, using the tests recommended by Grant and Lebo (2016). ${ }^{27}$

\section{Does mood respond to policy?}

We now examine the electoral turnover mechanism in two stages. In this section, we examine whether public preferences (as measured by the policy mood) respond to policy. In the next section, we examine whether vote intentions respond to the policy mood.

Previous research has established that preferences for policy $\left(R_{i j}\right)$ reflect the difference between ideal points $\left(P_{i}\right)$ and actual policy $\left(P_{j}\right)$ (Wlezien 1995).

$$
\mathrm{R}_{\mathrm{ij}}=\mathrm{P}_{\mathrm{i}}-\mathrm{P}_{\mathrm{j}}
$$

When actual policy exceeds the ideal $\left(P_{i}>P_{j}\right)$ then $R_{i j}>0$ and the electorate signal their preference for less. When a policy is less than ideal $\left(P_{i}<P_{j}\right)$ then $R_{i j}<0$ and the electorate signal their preferences for "more" activity. Preferences act like a "thermostat" (Wlezien 1995). The same logic applies to mood. As spending increases the public want less. Accordingly:

H1: The electorate move to the right as NMGE increases.

${ }^{26}$ For example, Keele et al. (2016) follow De Boef and Keele (2008) in arguing that error correction models can be applied to stationary data, while Esarey (2016) argues that they can usefully be applied to data generated by a partially differenced process.

${ }^{27}$ A further objection that could be made to our use of error correction models based on the work of Grant and Lebo (2016) is that our data are not really unit root given that our variables are bounded. They argue that fractionally differenced models are more appropriate in these cases. However, none of our variables come close to reaching their theoretical bounds. Esarey (2016) shows that the amount of data required to reliably estimate a fractionally differenced process is far larger than the 64 years of data we have, and also shows that an error correction model can provide a useful approximation to a fractionally differenced process when cointegration is present. 
The electorate prefers lower levels of direct tax taxation. Accordingly:

$\mathrm{H} 2$ : The electorate move to the right as average income tax increases.

Government activity is not the only influence on mood. Exogenous changes in the economy can also shape preferences. Increasing unemployment, for example, will lead the electorate to prefer more activity in order to reduce unemployment. ${ }^{28}$ Thus, independently of policy, the electorate will shift left as unemployment increases. These considerations suggest:

\section{H3: The electorate move to the left as unemployment increases.}

We model mood using an error correction model. Given that our variables are nonstationary and there is a cointegration relation between the dependent and independent variables, this is appropriate. ${ }^{29}$ The dependent variable is a mood. The independent variables are lagged values of average income tax levels, NMGE and unemployment.

Table 3 displays the estimated coefficients from the error correction model. The estimated error correction rate $(0.81)$ implies that over $80 \%$ of any deviation of preferences from the target rate in either direction is corrected within one year. The coefficients provide support for Hypotheses 1 and 2. The statistically significant negative coefficients for long-term effects for both NMGE $(b=-0.59)$ and average income tax rates $(b=-0.37)$ clearly suggest thermostatic relationships. There is also the short-term relationship between $\Delta x$ and $\Delta y$ for NMGE $(b=-0.59)$. As government activity increases, the electorate moves right and, as government activity decreases, it moves left. The long-term effect for unemployment also provides support for Hypothesis $3(b=0.86) .^{30}$

This evidence confirms the thermostatic hypothesis (Wlezien 1995). The electorate responds to both policy and economic conditions. Changing preferences communicate a desire to reduce government activity when "too hot" and increase it when "too cold". ${ }^{31}$ This is evidence of the first link in

${ }^{28}$ Similarly, inflation may lead the electorate to prefer less activity. Inflation is not statistically significant in the mood models and is omitted. This is the result of its high correlation with NMGE (Pearson's $R=0.60$, between 1948 and 2014).

${ }^{29}$ The augmented Dickey-Fuller score (lag level 3) for the equation in levels is -4.30 . Thus, the null hypothesis of nonstationarity in the error term is rejected at the $1 \%$ level, indicating that cointegration is present. The value of the error correction term is -0.81 with a standard error of 0.12 and thus a $t$-value of 6.75 . The $1 \%$ critical $t$-value for using this parameter as cointegration test with 64 observations and three variables is 4.23 (calculated from Ericsson and MacKinnon 2002). Thus we conclude cointegration is present.

${ }^{30}$ The effects for unemployment and spending reported here are generally stronger than those reported in Bartle et al. (2011). This is probably because this estimate of mood is only based on the core economic items and because government spending is measured by NMGE rather than TME.

31 This is consistent with Stimson's (1999) core finding that cycles occur between policy mood and government activity. 
Table 3. What drives the policy mood? (error correction model, 1948-2013)

\begin{tabular}{|c|c|c|}
\hline Error correction & $-0.81(0.12) * * *$ & $\begin{array}{l}t=6.75 \\
\text { MacKinnon } \mathrm{p}<0.01 \text { critical } t \text {-value: } 4.23\end{array}$ \\
\hline \multicolumn{3}{|l|}{ Unemployment $_{t-1}$} \\
\hline Long-term & $0.86(0.21) * * *$ & \\
\hline Short-term & $0.59(0.10)$ & \\
\hline \multicolumn{3}{|c|}{ Average direct tax $x_{t-1}$} \\
\hline Long-term & $-0.37(0.15)^{* *}$ & \\
\hline Short-term & $-0.11(0.35)$ & \\
\hline \multicolumn{3}{|c|}{ Domestic spending $_{t-1}$} \\
\hline Long-term & $-0.45(0.16)^{* * *}$ & \\
\hline Short-term & $-0.59(0.29) * * *$ & \\
\hline$N$ & 63 & \\
\hline Breusch-Godfrey & 0.03 & \\
\hline Adjusted $R^{2}$ & 0.44 & \\
\hline Root MSE & 2.66 & \\
\hline \multicolumn{3}{|c|}{ Augmented Dickey-Fuller value for integrating equation: -4.30 (lag order 3$)^{* * * *}$} \\
\hline
\end{tabular}

Note: $\mathrm{MSE}=$ mean square error.

$* * \mathrm{p}<0.01, * \mathrm{p}<0.05$.

the "chain of responsiveness" and representation. It is characteristic of both electoral turnover and policy accommodation mechanisms (Powell 2000). We now examine the next link in the electoral turnover mechanism: whether votes respond to mood.

\section{Policy mood and vote intentions}

Before proceeding, we must note that preferences are not the only the plausible influences on the vote: they are also influenced by long-term partisanship (Clarke et al. 2004), policy moderation (Nagel and Wlezien 2010) and evaluations of competence (Green and Jennings 2012). ${ }^{32}$ From this list of "usual suspects" we only have indicators of annual party competence. These are estimated using the dyads ratio algorithm and drawing on responses to survey questions about which party is best able to deal with any particular issue (Green and Jennings 2012). ${ }^{33}$ Unfortunately, we do not have annual indicators of partisanship or party position at our disposal. Partisanship was rarely measured in the 1950s and 1960s.

32 Policy moderation is defined in terms of the distance between the major party and the Liberal Democrats (or predecessors) in Nagel and Wlezien (2010).

${ }^{33}$ Assessments of party competence are estimated using Gallup, Ipsos-Mori and YouGov data gathered by the authors, separately from Green and Jennings (2012). 
Table 4. What drives annual vote intentions? (error correction model of Labour vote intentions, 1951-2015)

\begin{tabular}{lcl}
\hline \hline Error correction & $-0.57(0.12)^{* * *}$ & $\begin{array}{l}t=4.75 \\
\text { MacKinnon } \mathrm{p}<0.01 \text { critical } t \text {-value: } 3.29\end{array}$ \\
$\begin{array}{l}\text { Mood }_{t-1} \\
\quad \text { Long-term }\end{array}$ & $0.17(0.08)^{* * *}$ & \\
$\quad$ Short-term & $0.06(0.10)$ & \\
Macrocompetence $t-1$ & & \\
$\quad$ Long-term & $0.62(0.17)^{* * *}$ & \\
$\quad$ Short-term & $0.74(0.11)^{* * *}$ & \\
Constant & $-7.60(4.40)^{*}$ & \\
$N$ & 64 \\
Breusch-Godfrey & 2.34 \\
Adjusted $R^{2}$ & 0.52 \\
Root MSE & 2.24 \\
Augmented Dickey-Fuller value for integrating equation: -4.27 (lag order 3)*** \\
\hline
\end{tabular}

Note: $\mathrm{MSE}=$ mean square error.

$* * \mathrm{p}<0.01, * \mathrm{p}<0.05, * \mathrm{p}<0.1$.

The "traditional" measure of partisanship is, moreover, influenced by the same short-term factors that it is assumed to shape (Clarke et al. 2004). Accordingly, our vote intention model tests two hypotheses:

H4: Increasing evaluations of Labour's competence increase Labour vote.

H5: Leftwards shifts in the mood increase Labour vote.

Once again we use an error correction model, as there is cointegration between the dependent and independent variables. ${ }^{34}$ Table 4 assesses the relationship between annual Labour vote intentions, mood and evaluations of Labour competence between 1951 and 2015. The error correction term is significant and correctly signed $(b=-0.57)$ suggesting that $57 \%$ of any deviation of preferences from the target rate is corrected within one year. Both the long- and short-term coefficients for competence are significant and correctly signed ( $b=0.62$ and $b=0.74$, respectively) providing support for Hypothesis 4. Crucially, the coefficient for the long-term effect of mood

34 The augmented Dickey-Fuller score (lag level 3) for the equation in levels is -4.27 . Thus, the null hypothesis of nonstationarity in the error term is rejected at the $1 \%$ level, indicating that cointegration is present. The value of the error correction term is -0.57 with a standard error of 0.12 and thus a $t$-value of 4.75 . The $1 \%$ critical $t$-value for using this parameter as cointegration test with 64 observations and three variables is 3.29 (calculated from Ericsson and MacKinnon 2002). Thus we conclude cointegration is present. 
is significant $(b=0.17)$. As the mood moves left, Labour vote intentions increases. ${ }^{35}$ Hypothesis 5 is confirmed.

These results suggest that variations in mood have an electoral impact net of evaluations of competence. This provides some evidence for another step in the electoral turnover mechanism. The effect of competence is greater than mood. As a result, a move towards (say) the left in mood will not produce an increase in support for the Labour Party if there is even a small loss of confidence in the competence of the Labour Party.

\section{Party ideology, mood and policy representation}

We now examine whether policy responds to party incumbency or mood. If NMGE responds to party incumbency, this will confirm that governments pursue policy consistent with their ideology and provide evidence in favour of the electoral turnover mechanism. If it responds to mood, this will provide evidence in favour of the policy accommodation mechanism.

We did not find an appropriate cointegrating relationship, and so did not use an error correction model. Instead, we took the first difference of NMGE and regressed lagged mood, the change in unemployment and the change in inflation on this. This is similar to the approach in Soroka and Wlezien (2009). This specification is theoretically appropriate because our operationalisation of mood is intrinsically thermostatic. Respondents are typically not asked to name their ideal level of government spending on a programme; they are asked whether spending is too high, too low or about right. Left-wing mood means that the public demands more public spending than at present. As a result, we would expect the left-wing mood to produce an increase in spending.

If electoral turnover was producing a representation, who is in government should "make a difference" (Rose 1980). Labour governments should spend more than Conservative governments other things being equal. ${ }^{36}$ Accordingly, the electoral turnover model suggests:

H6: Labour governments have higher levels of NMGE than Conservative.

\footnotetext{
${ }^{35}$ Mood does not appear to influence Conservative or Liberal Democrat vote intentions. It should be noted that mood is significant in Labour vote models for general elections $(N=16)$ where controls are imposed for Labour's position (as represented by the RILE scores), a count variable (capturing unmeasured variables) and evaluations of competence.

36 Between 1945 and 2010 there were a total of eight turnovers of power $(1945,1951,1964$, 1970, February 1974, 1979, 1997 and 2010). The turnovers in 1951 and 1964 occurred late in the year, so in those years Labour are treated as the incumbents in 1951 and the Conservatives are treated as the incumbents in 1964. The turnover in February 1974 took place in February 1974 took place in early March, so Labour is treated as the incumbent government. In all other cases $(1945,1970,1979,1997$ and 2010), the turnover took place in the middle of the year and these are coded as 0 .
} 
If policy accommodation was producing a representation, NMGE should respond to the preferences communicated by variations in mood. The government could anticipate that the electorate will punish it if it does not deliver policies compatible with the mood of the electorate. This will lead to the government reacting to the current policy mood, perhaps with a lag. However, it could also anticipate what the mood the public will have at the time of the next election. If it is able to do this, then the future mood will have an effect on current policy. We test both possibilities.

\section{H7: Increases in the policy mood should increase NMGE.}

Table 5 displays the coefficients generated by five models. First, we model NMGE as a function of mood in the previous period, the change in unemployment and the previous period's inflation rate. In the second model, we take into account policy mood in each of the previous four years, to explore the effect of a change in mood over a five-year parliament. We then add political variables to each of these models, producing models 3 and 4. We include a variable representing whether Labour was in government, together with a dummy variable for 1974. Public spending in that year increased by $4.5 \%$ of GDP as a result of factors such as the oil crisis and the miners' strike (see Figure 2). Finally, in model 5 we consider whether the government's anticipation of the mood at the time of the next election has an effect on policy. We add a variable for the level of mood forecasted in the next period using the data available to that point. ${ }^{37}$

The first thing that is apparent from inspecting the five models is that mood has no significant effect on domestic spending - indeed the estimated coefficients are very close to 0 . This is true even if we add the effects of four lags of mood. The mood forecasted for the next period also does not have a statistically significant effect. These results are inconsistent with Hypothesis 8. There is no support for the idea that movements in mood lead to an increase in NMGE, whether we control for the effect of the party in government or not. There is no support for the policy accommodation mechanism.

By contrast, the coefficient for the party in government does have a significant effect. As importantly, this effect is substantially very significant. According to our models, Labour governments raise domestic spending by between 0.51 and $0.67 \%$ of GDP per year more than Conservative governments.

\footnotetext{
${ }^{37}$ We estimated a univariate autoregressive integrated moving average (ARIMA) model for our policy mood measure. The best fitting model involved differencing the mood once and had a first-order moving average term [ARIMA $(0,1,1)]$. The moving average term was -0.46 with a standard error of 0.11 , and the sigma for the overall model was 3.51 . This model was then used to create a forecast for each period based on the data from previous periods.
} 
Table 5. What drives annual policy? (modelling domestic government expenditure, 1949-2013)

\begin{tabular}{|c|c|c|c|c|c|}
\hline & Model 1 & Model 2 & Model 3 & Model 4 & Model 5 \\
\hline $\operatorname{Mood}_{t-1}$ & $-0.03(0.04)$ & $-0.07(0.06)$ & $0.00(0.04)$ & $-0.04(0.05)$ & $-0.41(0.73)$ \\
\hline $\operatorname{Mood}_{t-2}$ & & $-0.05(0.06)$ & & $0.00(0.06)$ & $-0.17(0.33)$ \\
\hline $\operatorname{Mood}_{t-3}$ & & $0.05(0.06)$ & & $0.01(0.05)$ & $-0.07(0.17)$ \\
\hline $\operatorname{Mood}_{t-4}$ & & $0.05(0.05)$ & & $0.04(0.04)$ & $-0.01(0.10)$ \\
\hline Forecasted mood & & & & & $0.68(1.32)$ \\
\hline Sum of lags and forecast (mood) & & $-0.01(0.04)$ & & $0.02(0.04)$ & $0.02(0.04)$ \\
\hline$\Delta$ Unemployment & $0.74(0.23)^{* * * *}$ & $0.69(0.24)^{* * *}$ & $0.80(0.20)^{* * *}$ & $0.78(0.21)^{* * * *}$ & $0.76(0.21)^{* * *}$ \\
\hline Inflation $_{t-1}$ & $-0.08(0.05)^{*}$ & $-0.08(0.05)^{*}$ & $-0.09(0.04) * *$ & $-0.09(0.04) * *$ & $-0.08(0.04) * *$ \\
\hline Labour in government & & & $0.67(0.32) * *$ & $0.60(0.34) *$ & $0.51(0.38)$ \\
\hline 1974 dummy & & & $4.64(1.18)^{* * *}$ & $4.65(1.21)^{* * *}$ & $4.70(1.23)^{* * *}$ \\
\hline Constant & $2.40(2.33)$ & $1.31(2.54)$ & $0.37(2.15)$ & $-0.60(2.34)$ & $-1.01(2.48)$ \\
\hline$N$ & 64 & 64 & 64 & 64 & 64 \\
\hline Adjusted $R^{2}$ & 0.12 & 0.12 & 0.34 & 0.33 & 0.32 \\
\hline MSE & 1.33 & 1.33 & 1.15 & 1.16 & 1.17 \\
\hline
\end{tabular}

Note: $\mathrm{MSE}=$ mean square error.

$* * \mathrm{p}<0.01, * \mathrm{p}<0.05, * \mathrm{p}<0.1$ 
Thus we find strong support for Hypothesis 8. Essentially parties keep pursuing the policies they are committed to, regardless of changes in public mood.

The effects of the various control variables are as expected. A change in unemployment leads to a very substantial increase in public spending. This is not unsurprising as unemployment directly increases spending on unemployment benefit and other social programmes. Inflation leads to small, but significant fall in spending. Again this is what we would expect as inflation makes it easier for governments to cut programmes by simply not fully indexing them. The dummy variable for 1974 also has the expected effect.

These findings confirm the impression in Figure 3. Simply put, "party matters" (Blais et al. 1996). Labour's reputation as the party of "big" or "bigger" government party is based on fact. So is the Conservative party's reputation as the party of "small" or "smaller" government. This part of the "electoral turnover" mechanism works very well - the parties offer voters a consistent and reliable choice between "more" or "less" government. We would expect that in the long-run changes in mood will lead to a change in government, which will, in turn, lead to a change in policy in line with public preferences. However, as we saw in the last section, the mood only has a weak effect on party support, and this can easily be overwhelmed by considerations of competence. ${ }^{38}$ Although we would expect "the electoral turnover" mechanism to work in the long-run, it may well fail for a considerable time if voters believe the opposition to be incompetent.

\section{Discussion}

The proposition that the electorate's preferences influences their votes seems implausible given what is known about the "typical voter" (Achen and Bartels 2016). Yet, in Britain, as in the United States (US), "our knowledge of the individual voter turns out not to be a reliable guide for generalising to the electorate and its role in democratic politics" (Erikson et al. 2002, 3). Variations in mood communicate real preferences and influence vote decisions. ${ }^{39}$ These "messages", however, are not acted on. Representation can only work by turning over power from "one side" to "the other". The parties play their part by reliably pursuing policies consistent with their left-right ideology.

Our findings contrast with other studies that suggest that there is a degree of policy accommodation. Soroka and Wlezien's (2009) study, for example,

38 The impact of mood may be different if we had a reliable annual measure of party position.

39 Biases in the electoral system may reduce policy responsiveness (Johnston et al. 2012). 
uncovered evidence of policy representation in specific domains such as defence, social affairs, health and education between 1978 and $1995 .{ }^{40}$ Preferences in those domains responded thermostatically to spending. Policy, in turn, responded to preferences. Soroka and Wlezien measure preferences using responses to specific Gallup questions about whether spending in those domains should be increased or decreased and they measure policy by spending in the same domains. This approach assumes that variations in these individual series reflect preferences and spending in a particular domain. ${ }^{41}$ It seems wholly reasonable to suggest, however, that preferences in those domains may also partly reflect the general policy mood and overall spending. The observed "thermostatic" effect may well reflect the diminishing marginal utility of spending in that domain, but it may also reflect the electorate's ambivalence to government activity - in particular, its aversion to taxes and borrowing. This is particularly the case in those areas of government activity that account for a large share of spending. ${ }^{42}$ It might be informative, therefore, to repeat Soroka and Wlezien's analyses controlling for the policy mood (less those items relating to a specific domain) and overall spending. ${ }^{43}$ The overall budget constraint must also impose constraints on spending and responsiveness.

Our findings also contrast with Erikson et al.'s study of responsiveness and representation in the US, which concluded that policy was sensitive to preferences. This study, like our own, used mood to measure preferences. ${ }^{44}$ Policy was measured, however, using congressional rating scales and roll call outcomes (Erikson et al. 2002, 294-295). ${ }^{45}$ Analogous indicators are not available in the British case. Even if such measures were available, they would have less validity. Party discipline is strong and there are few defections on ideological votes (Cowley 2002). It may be that the US system

40 Their study also covered representation in the US and Canada.

${ }^{41}$ Soroka and Wlezien used lagged dependent variables. The results are laid out in Soroka and Wlezien $(2009,96$, table 5.2).

${ }^{42}$ Soroka and Wlezien $(2009,170)$ recognise that thermostatic responses and policy accommodation are more likely in the most "important" domains. Importance is presumably correlated with total spending. They were unable to examine the welfare domain because reliable time series data on welfare spending was not available (Soroka et al. 2006). Welfare accounted for around $35 \%$ of total government spending in 2015 .

${ }^{43}$ Just as in our analyses, Soroka and Wlezien measure policy by budgets. Spending, however, is measured in real terms rather than as a percentage of GDP. This difference does not account for our findings. Replacing NMGE as a proportion of GDP with TME in real terms makes no difference. There is no evidence of policy accommodation.

44 They imposed fewer assumptions than we do here and included many items relating to "social issues". This is unlikely to make any difference for reasons outline above.

${ }^{45}$ Erikson et al. (2002) produce indicators for both the House of Representatives and President. This makes little sense in Britain, given the effective "fusion" of the legislature and executive. 
of checks and balances ensures that preferences are taken into consideration (Powell 2000). The same may be true of "consensus" democracies (Lijphart 1999). There is clearly a need for collaborative research along the lines of the Comparative Agendas Project (Baumgartner et al. 2009).

Our results also differ greatly from those of Hakhverdian (2010), who argues that there is a high degree of policy responsiveness in the British case, and furthermore that this is the result of "rational anticipation", a process roughly equivalent to what we refer to as "policy accommodation". However, the different results are unsurprising when we consider how Hakhverdian measures government policy. Like us, Hakhverdian seeks to explain how left- or right-wing government policy is. However, unlike us he does not measure this in terms of government actions, such as tax and spending decisions, but rather by the content of budget speeches, using the Wordscores programme (Laver et al. 2003). ${ }^{46}$ It seems that when public opinion moves to the left, governments include more left-wing themes in their budget statements, but do not change tax or spending behaviour.

Our findings also appear to contrast with the policy agendas literature (Jennings and John 2009; Bertelli and John 2013; John et al. 2013; Bevan and Jennings 2014). This literature demonstrates that government attention (as measured by the content of the official policy speeches) is responsive to the public's policy agenda (as measured by responses to the most important issue or most important problem question). This contrast is, however, more apparent than real, as quite different things are being measured. British governments appear to be responsive in the sense of addressing the issues that the public thinks are important. However, when it comes to decisions about the level of spending, they follow their party ideologies.

\section{Conclusions}

Our results suggest that domestic spending policy is not responsive to mood and is driven, instead, by economic conditions and party control (Strøm 1990; Blais et al. 1996). That is to say, we do not find evidence of "policy accommodation" by governments - governments pursue policies consistent with their ideologies unaffected by changes in public opinion.

46 The Wordscores programme essentially compares word frequencies in reference and virgin texts. The application of these methods to long time series is a cause of concern since the vocabulary of politics is likely to change over 70 years. The choice of reference texts is of crucial importance. Hedging by using a large number of references texts tends to "flatten out" variations (Budge and Pennings 2007). There are other issues: "estimated document scores are on the wrong scale and the theoretical development does not specify a statistical model, so it is unclear what assumptions the method makes about political text and how to tell whether they fit particular text analysis applications" (Lowe 2008, 356). 
The unresponsiveness of governments seems surprising given the "power hoarding" nature of the British constitution (King 2007). British governments are guaranteed a parliamentary majority. The government at Westminster is not constrained by federal structures. The principle of parliamentary sovereignty, moreover, implies that the courts do not have the power of constitutional review. British governments have the power to either respond to or anticipate the impact of preferences - but they do not appear so.

We do find evidence that public opinion may affect policy through the mechanism of "electoral turnover". We find that changes in policy mood affect voting intentions. If policy mood moves against the ideology of the current government, it will lose support and eventually be replaced by a government whose ideology reflects the public's mood. This should lead to a correction in policy in line with public opinion. However, this process may take a considerable amount of time. We find that the effect of policy mood on voting intentions is not as strong as the effect of people's assessment of government competence. If the public lacks faith in the competence of the opposition, the government may retain power for a considerable amount of time, even though it may be moving policy in the opposite direction the public wants.

One reason for our findings may be that the "mandate" from the previous general election has greater moral force than the requirement to adjust policies to current opinion. If a strategy of policy accommodation were followed, moreover, it would erode a party's reputation for reliability and responsibility (Downs 1957). Governments may follow their ideological impulses to maintain appeals to members, donors or core voters (Jacobs and Shapiro 2000). Trimming policy to reflect the "feedback" from public preferences may create intraparty tensions (Budge et al. 2010). Conservative governments that increase taxes, for example, will outrage business interests and the middle class. Labour governments that cut spending will antagonise trade unions and public sector workers. The policy may be responsive to majority opinion within governing parties (Hussey and Zaller 2011).

Even if governing parties were willing - in principle - to respond to mood, they may not be able to detect it. Evidence about public preferences largely comes from snapshots of opinion. Viewed in cross-section, however, preferences are characterised by considerable ambivalence. People often appear to take "different sides" on the same issue and different "sides" on "seemingly related" issues (Stimson 2004). The typical snapshots of preferences on diverse issues may communicate no clear signal. Indeed, the sheer amount of data may produce considerable uncertainty about "what the public want " (Jacobs and Shapiro 2000; Druckman and Jacobs 2006). The mood is only uncovered once issues are standardised in terms of left 
and right and then aggregated (Converse 1990). It is understandable that governments fall back on ideology (Budge 1994).

Given this uncertainty about what people want, it seems only reasonable to suggest that politicians will select evidence or interpret trends in ways that are politically congenial. Ideology provides the emotional basis for the sort of "motivated reasoning" (Epley and Gilovich 2016). Comments such as "it's not what we are hearing on the doorstep" may reflect either unconscious biases or wilful ignorance but both result in a failure to "receive" discomforting feedback (Kingdon 1967). Finally, even if governments can "hear" the change of mood and even if they are prepared to act on it, they may believe that other factors - such as the "costs of the ruling" will lead to their inevitable defeat (Naanstead and Paldam 2002). If governments believe that the swings of the pendulum operate independently of policy they may well fall back on their ideology (Budge 1994).

\section{Acknowledgements}

This research was supported by research grants to the first named author by the Economic and Social Research Council (award number RES-00022-2053) and a British Academy Mid-Career Fellowship (award number MD130098). The authors would like to thank Jim Stimson for advice on the implementation of the dyads ratio algorithm and Frances Lynch for supplying data on average tax rates. Preliminary drafts of this article were presented at the workshop on "Public Opinion and Public Policy Analysing Feedback Effects in Comparative Politics" at the ECPR Joint Sessions, 24-28 April 2016 and the Elections Public Opinion and Parties specialist conference of the Political Studies Association at the University of Kent, 9-11 September 2016. The authors would like to pay particular thanks to Ian Budge for his detailed comments.

\section{Supplementary material}

To view supplementary material for this article, please visit https://doi.org/ $10.1017 /$ S0143814X18000090

\section{References}

Achen C. H. and Bartels L. M. (2016) Democracy for Realists: Why Elections Do Not Produce Representative Government. Princeton, NJ: Princeton University Press.

Bartle J., Dellepiane Avellaneda S. and Stimson J. A. (2011) The Moving Centre: Preferences for Government Activity in Britain, 1950-2005. British Journal of Political Science 41(2): 259-285.

Baumgartner F., Green-Pedersen C. and Jones B. D. (eds.) (2009) Comparative Studies of Policy Agendas. London: Routledge. 
Bertelli A. and John P. (2013) Public Policy Investment: Risk and Return in British Politics. British Journal of Political Science 43(4): 741-773.

Bevan S. and Jennings W. (2014) Representation, Agendas and Institutions. European Journal of Political Research 53(1): 37-56.

Blais A., Blake D. and Dion S. (1993) Do Parties Make a Difference? Parties and the Size of Government in Liberal Democracies. American Journal of Political Science 37(1): 40-62.

Blais A., Blake D. and Dion S. (1996) Do Parties Make a Difference? A reappraisal. American Journal of Political Science 40(2): 514-520.

Budge I. (1994) A New Spatial Theory of Party Competition: Uncertainty, Ideology and Policy Equilibria Viewed Comparatively and Temporally. British Journal of Political Science 24(4): 443-467.

Budge I. (2006) Identifying Ideologies and Locating Parties. In Katz I. and Crotty W. (eds.), Handbook of Party Politics. Beverly Hills, CA: Sage Publications, 422-433.

Budge I. and Farlie D. (1977) Voting and Party Competition. London: Wiley.

Budge I. and Pennings P. (2007) Do they work? Validating computerised word frequency estimates against policy series. Electoral Studies 26(1): 121-129.

Budge I., Klingemann H. D., Volkens A., Bara J. and Tanenbaum E. (2001) Mapping Policy Preferences: Estimates for Parties, Electors, and Governments 1945-1998. Oxford: Oxford University Press.

Budge I., McDonald M. D. and Ezrow L. (2010) Ideology, Party Factionalism and Policy Change: An Integrated Dynamic Theory. British Journal of Political Science 40(4): 781-804.

Burke E. (2009) Letter to the Sheriffs of Bristol. In Stanlis P. (ed.), Selected Writings and Speeches. New Brunswick: Transaction Books, 223-252.

Carmines E. G. and Stimson J. A. (1989) Issue Evolution: Race and the Transformation of American Politics. Cambridge: Cambridge University Press.

Christiano T. (1996) The Rule of the Many: Fundamental Issues in Democratic Theory. Boulder, CO: Westview Press.

Clarke H. D., Stewart M. C., Sanders D. and Whiteley P. (2004) Political Choice in Britain. Cambridge: Cambridge University Press.

Converse P. E. (1990) Popular Representation and the Distribution of Information. In Ferejohn J. and Kuklinski J. (eds.), Information and Democratic Processes. Urbana, IL: University of Illinois Press, 369-388.

Cowley P. (2002) Revolts and Rebellions: Parliamentary Voting Under Blair. London: Politico's.

Dahl R. (1956) A Preface to Democratic Theory. Chicago, IL: University of Chicago Press.

De Boef S. and Keele L. (2008) Taking Time Seriously. American Journal of Political Science 52(1): 184-200.

Downs A. (1957) An Economic Theory of Democracy. New York: Harper \& Row.

Druckman J. N. and Jacobs L. R. (2006) Lumpers and Splitters: The Public Opinion Information that Politicians Collect and Use. Public Opinion Quarterly 70(4): 453-476.

Ellis C. and Stimson J. A. (2012) Political Ideology in America. Cambridge: Cambridge University Press.

Enders W. (2004) Applied Econometric Time Series. Hoboken, NJ: John Wiley \& Sons.

Engle R. F. and Granger C. W. J. (1987) Co-Integration and Error Correction: Representation, Estimation, and Testing. Econometrica 55(2): 251-276.

Enns P. K., Kelly N. J., Masaki T. and Wohlfarth P. C. (2016) Don't Jettison the General Error Correction Model Just Yet: A Practical Guide to Avoiding Spurious Regression with the GECM. Research and Politics 3(2): 1-13.

Epley N. and Gilovich T. (2016) The Mechanics of Motivated Reasoning. Journal of Economic Perspectives 30(3): 133-140. 
Ericsson N. R. and MacKinnon J. G. (2002) Distributions of Error Correction Tests for Cointegration. Econometrics Journal 5(2): 285-318.

Erikson R. S., MacKuen M. D. and Stimson J. A. (2002) The Macro Polity. Cambridge: Cambridge University Press.

Esarey J. (2016) Fractionally Integrated Data and the Autodistributed Lag Model: Results from a Simulation Study. Political Analysis 24(1): 42-49.

Fishkin J. (1995) The Voice of the People: Public Opinion and Democracy. New Haven, CT: Yale University Press.

Grant T. and Lebo M. J. (2016) Error Correction Methods with Political Time Series. Political Analysis 24(1): 3-30.

Green J. and Jennings W. (2012) Valence as Macro-Competence: An Analysis of Mood in Party Competence Evaluations in Great Britain. British Journal of Political Science 42(2): 311-343.

Hakhverdian A. (2010) Political Representation and its Mechanisms: A Dynamic Left-Right Approach for the United Kingdom, 1976-2006. British Journal of Political Science 40(4): 835-856.

Heath A., Evans G. and Martin J. (1994) The Measurement of Core Beliefs and Values: The Development of Balanced Socialist/Laissez Faire and Libertarian/Authoritarian Scales. British Journal of Political Science 24(1): 115-138.

Hussey W. and Zaller J. R. (2011) Who Do Parties Represent?. In Enns P. K. and Wlezien C. (eds.), Who Gets Represented? New York: Russell Sage Foundation, 311-344.

Jacobs L. R. and Shapiro R. Y. (2000) Politicians Don't Pander: Political Manipulation and the Loss of Democratic Responsiveness. Chicago, IL: Chicago University Press.

Jennings W. and John P. (2009) The Dynamics of Political Attention: Public Opinion and the Queen's Speech in the United Kingdom. American Journal of Political Science 53(4): 838-854.

Jennings W. and Wlezien C. (2015) Preferences, Problems and Representation. Political Science Research \& Methods 3(3): 659-681.

John P., Bertelli A. M., Jennings W. J. and Bevan S. (2013) Policy Agendas in British Politics, Comparative Studies of Political Agendas Series. Basingstoke: Palgrave MacMillan.

Johnson P., Lynch F. and Walker J. G. (2005) Income Tax and Elections in Britain, 1950-2001. Electoral Studies 24(3): 393-408.

Johnston R., Pattie C., Dorling D. and Rossiter D. (2012) From Votes to Seats: The Operation of the UK Electoral System Since 1945. Manchester: Manchester University Press.

Kavanagh D. (1988) Thatcherism and British Politics: The End of Consensus?. Oxford: Oxford University Press.

Keele L., Linn S. and Webb C. M. (2016) Treating Time With All Due Seriousness. Political Analysis 24(1): 31-41.

King A. (2007) The British Constitution. Oxford: Oxford University Press.

Kingdon J. W. (1967) Politicians' Beliefs About Voters. American Political Science Review 61(1): 137-145.

Laver M., Benoit K. and Garry J. (2003) Extracting Policy Positions from Political Texts Using Words as Data. American Political Science Review 97(2): 311-331.

Lijphart A. (1999) Patterns of Democracy: Government Forms and Performance in Thirty-Six Countries. New Haven, CT: Yale University Press.

Lowe W. (2008) Understanding Wordscores. Political Analysis 16(4): 356-371.

MacKinnon J. G. (1994) Asymptotic Distribution Functions for Unit-Root and Cointegration Tests. Journal of Business \& Economic Statistics 12(2): 167-176.

Mansbridge J. (2003) Rethinking Representation. American Political Science Review 97(4): $515-528$.

May J. D. (1978) Defining Democracy: A Bid for Coherence and Consensus. Political Studies 26(1): 1-14. 
McDonald M. D. and Budge I. (2005) Elections, Parties. Democracy: Conferring the Median Mandate. Oxford: Oxford University Press.

McGann A. (2014) Estimating the Political Center from Aggregate Data: An Item Response Theory Alternative to the Stimson Dyad Ratios Algorithm. Political Analysis 22(1): 115-129.

Naanstead P. and Paldam M. (2002) The Costs of Ruling. In Dorussen H. and Taylor M. (eds.), Economic Voting. London: Routledge, 17-44.

Nagel J. H. and Wlezien C. (2010) Centre-Party Strength and Major Party Divergence in Britain, 1945-2005. British Journal of Political Science 40(2): 279-304.

Organisation for Economic Co-operation and Development (2017) Governments at a Glance. Paris: OECD Publishing.

Petitt P. (2010) Varieties of Public Representation. In Shapiro I., Stokes S. C., Wood E. J. and Kirshner A. S. (eds.), Political Representation. Cambridge: Cambridge University Press, 61-89.

Powell G. B. (2000) Elections as Instruments of Democracy: Majoritarian and Proportional Systems. Yale, CT: Yale University Press.

Przeworski A. (1999) Minimalist Conception of Democracy: A Defense. In Shapiro I. and Hacker-Cordòn C. (eds.), Democracy's Values. Cambridge: Cambridge University Press, 23-55.

Rehfeld A. (2009) 'Representation Rethought: On Trustees, Delegates, and Gyroscopes in the Study of Political Representation and Democracy'. American Political Science Review 103(2): 214-230.

Riker W. (1982) Liberalism Against Populism: A Confrontation Between the Theory of Democracy and the Theory of Social Choice. San Francisco, CA: Freeman.

Rose R. (1980) Do Parties Make a Difference?. London: Macmillan.

Scarbrough E. (1984) Political Ideology and Voting Behaviour: An Exploratory Study. Oxford: Clarendon Press.

Schumpeter J. (1942) Capitalism, Socialism and Democracy. New York: Harper \& Brothers.

Soroka S. N. and Wlezien C. (2009) Degrees of Democracy: Politics, Public Opinion, and Policy. Cambridge: Cambridge University Press.

Soroka S. N., Wlezien C. and McLean I. (2006) Public Expenditure in the UK: How Measures Matter. Journal of the Royal Statistical Society Series A. 166(2): 255-271.

Stimson J. A. (1999) Public Opinion in America: Moods, Cycles and Sings. Boulder, CO: Westview Press.

Stimson J. A. (2004) Tides of Consent: How Public Opinion Shapes American Politics. Cambridge: Cambridge University Press.

Stimson J.A., MacKuen M. D. and Erikson R. S. (1995) Dynamic Representation. American Political Science Review 89(3): 543-565.

Stokes D. E. (1963) Spatial Models of Party Competition. American Political Science Review 57(2): 368-377.

Strøm K. (1990) A Behavioural Theory of Competitive Political Parties. American Journal of Political Science 34(2): 565-598.

Treasury H. M. (2016) Budget 2016, https://www.gov.uk/government/uploads/system/uploads/ attachment_data/file/508193/HMT_Budget_2016_Web_Accessible.pdf

Weber M. (1978) Economy and Society: An Outline of Interpretive Sociology. Volume 1. Berkeley, CA: University of California Press.

Wlezien C. (1995) The Public as Thermostat: Dynamics of Preferences for Spending. American Journal of Political Science 39(4): 981-1000.

Zaller J. R. and Feldman S. (1992) A Simple Theory of the Survey Response: Answering Questions Versus Revealing Preferences. American Journal of Political Science 36(3): 579-616. 
